\title{
Mapping ELE Initiatives: Approaches, Underlying Assumptions, and Con- ceptual Challenges
}

Dr. Donna M. Riley, Virginia Polytechnic Institute and State University

Donna Riley is Professor of Engineering Education at Virginia Tech.

Dr. Dean Nieusma, Rensselaer Polytechnic Institute

Dean Nieusma is Associate Professor in Science and Technology Studies and Director of the Programs in Design and Innovation at Rensselaer. 


\section{Mapping Engineering and Liberal Education Initiatives: Approaches, Underlying Assumptions, and Conceptual Challenges}

The objective is not to turn us into amateur ethnographers, sociologists, or educators but to understand the complexities of the fields that have come before us, learn some of their tools, and employ them in the fertile territory of art [or engineering]. - Pablo Helguera ${ }^{1}$

\section{Introduction}

This paper critically interprets a set of purportedly exemplary engineering and liberal education (ELE) integration approaches identified by the collaborative ASEE and Teagle Foundation initiative, titled the "Engineering-Enhanced Liberal Education Project." Drawing on theoretical insights from science and technology studies and engineering studies, the paper considers how the ELE approaches represented within the Engineering-Enhanced Liberal Education (EELE) Project manifest or resist (or at times both) some of the conceptual challenges of traditional engineering epistemologies and how they align with or contradict the conceptual foundations of liberal education as traditionally understood.

As articulated by the American Association of Colleges and Universities (AAC\&U), liberal education is

an approach to college learning that empowers individuals and prepares them to deal with complexity, diversity, and change. This approach emphasizes broad knowledge of the wider world (e.g., science, culture, and society) as well as indepth achievement in a specific field of interest. It helps students develop a sense of social responsibility; strong intellectual and practical skills that span all major fields of study, such as communication, analytical, and problem-solving skills; and the demonstrated ability to apply knowledge and skills in real-world settings. ${ }^{3}$

For the purposes of the present analysis, a critical facet of liberal education is its intellectual and disciplinary breadth. The AAC\&U statement goes on to elaborate the breadth component of liberal education specifically, highlighting that liberal education curricula usually entail "broad learning in multiple disciplines and ways of knowing." is a critical point of inquiry when assessing ELE integration efforts.

The analysis presented in this paper is part of a larger research initiative being carried out by the authors, which interrogates a wider range of approaches to ELE integration with the goal of identifying the strategic and conceptual dimensions that drive them and some of their associated underlying assumptions. ${ }^{5,6}$ The larger project seeks to provide a map of current and proposed engineering programs that explicitly highlight ELE integration, drawing particularly on venues such as ASEE Liberal Education/Engineering and Society Division, Union College's annual 
Engineering and Liberal Education Symposium, and the related set of initiatives around the theme of engineering and social justice as well as some of the many books, professional society and government reports, and strategic initiatives by foundations.

In the context of that larger project, this paper will focus on the EELE initiative and the 12 exemplary case studies identified by the initiative's lead, Shelia Tobias. ${ }^{7}$ We focus our analysis on how the case studies contextualize engineering content and educational approaches with respect to traditional understandings of liberal education and its learning objectives. We argue that, across many of these case studies, despite the purported framing of engineering "enhancing liberal education," there exists an explicit or implicit rejection of foundational principles of liberal education. Typically, this rejection comes in the form of educational approaches that inadvertently undermine the legitimacy of non-empiricist, non-technocentric modes of inquiry, either absolutely or relative to the greater epistemic authority of engineering and the physical and natural sciences.

To support this argument, this paper systematically explores the EELE cases along three dimensions: 1) How engineering inquiry is positioned relative to traditional liberal education modes of inquiry; 2) How the interactions between technology and society are framed, including where the motive force for social change is located; and 3) How the "fundamentals" of engineering are understood in relation to the steering of technology in broader social, political, and organizational contexts. Before elaborating each of these dimensions, we review the methodology used in analyzing the case studies and provide a brief map of those case studies in light of our analytic goals.

\section{Methodology}

To analyze how the EELE Project frames engineering content and educational approaches with respect to traditional understandings of liberal education, the authors reviewed all content included within ASEE's EELE Project website, focusing most closely on the 12 exemplary case studies available on the site as of February 2017. The 12 case studies provide an overview of a greater number of courses as well as educational interventions at higher levels, including minors, honors programs, general education curricular requirements, and some attention to educational institution administration and strategy setting. However, the scope of our analysis is limited to the 12 cases provided, and does not extend to the programs or institutions within which those specific cases are situated.

The authors applied a combined content and discourse analysis method to the case material, in order both to interpretively analyze the cases before us ${ }^{8}$ and, at the same time, to document how norms are communicated, how and why particular practices develop, and how reality is constructed within our community of study. ${ }^{9}$ The case material was first coded for key concepts 
related to the larger research project (as described above and elaborated below). Recurring themes were then identified and instances of those themes were subjected to interpretive analysis and elaborated from the perspective of critical discourse analysis with a view to determining how and why certain normative practices develop in these courses and programs.

The EELE Project situates itself within the broader "technological literacy" space, that is, incorporating engineering content into liberal or general education initiatives. Rather than focus on how engineers come to experience a liberal education, the EELE initiative is focused on how non-engineers do or ought to come to learn about engineering. Our analysis of these efforts, therefore, is focused on how engineering is presented and communicated to non-engineering student communities. These case studies reflect decisions about what non-engineers need to know about engineering, and how engineering relates to society in contemporary or historical contexts, which reveal much about how engineering and liberal education are constituted in this community of educators.

\section{Mapping the Space}

Shelia Tobias opens her inventory of EELE initiatives with an editor's introduction that provides context for the case studies constituting the primary content of the site. She opens her introduction with a claim - ambiguously referencing Domenico Grasso, currently Provost at the University of Delaware, and James Duderstadt, President Emeritus of the University of Michigan - that there is "a growing consensus that 'technological literacy' has to be grounded in the intellectual discipline of engineering." 10 Tobias then overviews some of the historical precedents for directing attention to technological literacy education and some of the institutional and administrative opportunities and challenges facing the scale-up of technological literacy educational initiatives. Despite the existence of plenty of "decentralized" initiatives, what's missing in the growth of these initiatives, Tobias concludes, is "the kind of synergy that might have come from reporting more broadly what is going on at the grass roots ... [with] 'about engineering' courses for non-engineers."

Table 1 provides an overview of the content of the 12 case studies included in the EELE project as of February 2017, including summarizing the intervention modality, main pedagogical approaches, and major learning goals associated with each initiative. 


\begin{tabular}{|c|c|c|c|}
\hline Institution & Modality & Pedagogical Approach & Learning Goals \\
\hline Princeton & $\begin{array}{l}\text { Two history-of- } \\
\text { technology courses }\end{array}$ & $\begin{array}{l}\text { "Great works of } \\
\text { engineering" }\end{array}$ & $\begin{array}{l}\text { "integration of numerical understanding } \\
\text { with [qualitative] analysis" }\end{array}$ \\
\hline Delaware & $\begin{array}{l}\text { Five survey engineering } \\
\text { and technology-and- } \\
\text { society courses }\end{array}$ & $\begin{array}{l}\text { Engineering principles } \\
\text { and how technologies } \\
\text { work }\end{array}$ & $\begin{array}{l}\text { "more non-engineers comfortable with } \\
\text { today's complex technological problems" }\end{array}$ \\
\hline Delaware & $\begin{array}{l}\text { One course taught } \\
\text { within honors program }\end{array}$ & $\begin{array}{l}\text { Engineering principles, } \\
\text { how technologies work }\end{array}$ & $\begin{array}{l}\text { "more non-engineers comfortable with } \\
\text { today's complex technological problems" }\end{array}$ \\
\hline Macalester & $\begin{array}{l}\text { Proposed course on how } \\
\text { engineers think }\end{array}$ & $\begin{array}{l}\text { How technologies } \\
\text { work, technologies' } \\
\text { social contexts }\end{array}$ & $\begin{array}{l}\text { Engineering design as inherently } \\
\text { technical, social, political, ethical }\end{array}$ \\
\hline Williams & $\begin{array}{l}\text { Co-taught course on } \\
\text { applied science } \\
\text { applications }\end{array}$ & $\begin{array}{l}\text { Question-posing; } \\
\text { exploring intersections } \\
\text { of technical and ethical } \\
\text { dimensions of } \\
\text { technology applications }\end{array}$ & $\begin{array}{l}\text { Students "to determine which tools } \\
\text { [engineering, ethical] they will need to } \\
\text { solve [a given] problem" involving the } \\
\text { application of advanced technologies }\end{array}$ \\
\hline Smith & $\begin{array}{l}\text { Two versions of intro } \\
\text { engineering course for } \\
\text { majors and non-majors }\end{array}$ & $\begin{array}{l}\text { Stages of engineering } \\
\text { design plus technology- } \\
\text { and-society }\end{array}$ & $\begin{array}{l}\text { Impacts of engineering on society; } \\
\text { quantitative analysis used in design }\end{array}$ \\
\hline Wellesley & $\begin{array}{l}\text { Historical context of } \\
\text { Technology Studies } \\
\text { Program and its courses }\end{array}$ & $\begin{array}{l}\text { Students to understand } \\
\text { and apply engineering's } \\
\text { "big ideas," engineers" } \\
\text { "habits of mind" }\end{array}$ & $\begin{array}{l}\text { "to engage critically with content related } \\
\text { to engineering and technology" with the } \\
\text { grounding principle of "engineering as a } \\
\text { humanitarian profession" }\end{array}$ \\
\hline $\begin{array}{l}\text { Stony } \\
\text { Brook }\end{array}$ & $\begin{array}{l}\text { Two courses that satisfy } \\
\text { the general education } \\
\text { "tech" requirement- } \\
\text { one tech-and-society, } \\
\text { one materials science }\end{array}$ & $\begin{array}{l}\text { How engineers } \\
\text { think/analyze vs how } \\
\text { laypeople do; } \\
\text { fundamentals of } \\
\text { materials, exemplified } \\
\text { with everyday techs }\end{array}$ & $\begin{array}{l}\text { Apply tools from any field to investigate } \\
\text { relationship between sci/tech and } \\
\text { arts/humanities/social sciences; } \\
\text { synthesize quantitative/tech with } \\
\text { qualitative info; apply fundamental } \\
\text { principles to real-world questions }\end{array}$ \\
\hline $\begin{array}{l}\text { Iowa State } \\
\& \text { Ohio } \\
\text { State }\end{array}$ & $\begin{array}{l}\text { Two institutions' } \\
\text { engineering minor } \\
\text { programs }\end{array}$ & $\begin{array}{l}\text { "What engineers do and } \\
\text { how they think about } \\
\text { what they do"; } \\
\text { engineering and policy; } \\
\text { technology literacy as } \\
\text { component of gen ed }\end{array}$ & $\begin{array}{l}\text { "Understanding technology, technological } \\
\text { development, and social, ethical, and } \\
\text { environmental aspects of technology"; } \\
\text { range of domain areas of engineering } \\
\text { practice: design, analysis, manufacturing, } \\
\text { benefit/risk analysis }\end{array}$ \\
\hline Hope & $\begin{array}{l}\text { B.S. engineering } \\
\text { program, with emphasis } \\
\text { on program's gateway } \\
\text { course }\end{array}$ & $\begin{array}{l}\text { "the structure and } \\
\text { function of modern } \\
\text { technology from a } \\
\text { systems-thinking } \\
\text { perspective"; how } \\
\text { engineers think/work }\end{array}$ & $\begin{array}{l}\text { How to understand components of } \\
\text { technical systems and how technical } \\
\text { systems interact with "outside systems: } \\
\text { social, cultural, economic" }\end{array}$ \\
\hline Wesleyan & $\begin{array}{l}\text { Institutional emphasis } \\
\text { area in "design and } \\
\text { engineering" with } \\
\text { experimental course } \\
\text { offerings by visiting } \\
\text { faculty }\end{array}$ & $\begin{array}{l}\text { Design and design } \\
\text { thinking paradigm to } \\
\text { connect technology } \\
\text { with traditional liberal } \\
\text { education subject areas }\end{array}$ & $\begin{array}{l}\text { Primarily an administrative vision } \\
\text { statement, where learning objectives are } \\
\text { not clearly specified }\end{array}$ \\
\hline
\end{tabular}

Table 1: ASEE's Engineering-Enhanced Liberal Education Exemplary Cases 


\section{Epistemological Elitism: Engineering within a Liberal Educational Framework}

Perhaps the most troubling conceptual shortcoming represented across many of the EELE case studies is a common variety of technoscientific elitism, lauding engineers and engineering as intellectually if not morally superior to those from other academic disciplines, not least those within disciplines traditionally associated with the liberal arts. This elitism is never represented maliciously, and presumably is not intentional; in most cases is likely merely to be a reflection of the norms already evident in engineering education. Nevertheless, we see repeated framings of the case material in ways that highlight the challenges of "bringing up" liberal arts students to the level of engineering students or, the inverse, highlighting the importance of finding strategies to make engineering content "accessible" to non-majors.

One example of this type of elitism is evidenced in the Delaware case, where the relevant engineering courses target liberal arts students, who come with "very different backgrounds and levels of understanding," many of whom found "what engineers would consider simple mathematics intimidating." 12 This framing assumes different backgrounds entail different levels of understanding, rather than different types of understanding, and that mathematics is somehow an arbiter of higher-level knowledge. A very similar example is how course planners at Iowa State understood the extent to which engineering content required modification for non-majors. The case brief describes how faculty members

were surprised to discover how little they had to modify [their] classes to serve nonmajors. Simply by assessing non-engineering students by means of separate tests and not requiring them to do the more advanced assignments, non-engineers were being accommodated. The faculty ... tested concepts over rigor. (italics added) ${ }^{13}$

The epistemological elitism on display here is of two kinds. First is the surprise that nonengineers can approximate learning of content overlapping with their courses, even if that content is watered-down in terms of its technical analytic specialization. Second is that the shifting of emphasis from specialized to generalized content entails "not requiring ... advanced" work, and worse, requires stripping the "rigor." In each instance, non-engineering students are cast as intellectually inferior to their engineering peers.

The claims that non-engineers require lower-level, less-advanced content misses the obvious insight that different disciplines entail different types of "advanced" content. Giving the authors the benefit of the doubt, however, we might assume they simply mean "less advanced in terms of technical analysis." It is difficult, however, to be equally generous with the claim that nonengineers require "concepts over rigor." Of course, any non-major in any field would benefit by being introduced to the field's main concepts rather than the specific, "advanced" tools used within the discipline, but to suggest that engineering's inquiry is rigorous, but other disciplines' inquiry is not, is epistemologically elitist without qualification. 
In the same case brief, this time discussing the Ohio State initiative, the case authors respond to concerns about integrating engineering majors with those (only) pursuing an engineering minor: "The argument for joint enrollment is that graduate engineers often have to work with clients who do not have a full engineering background" (italics added). ${ }^{14}$ The elitism on display here is less in assessing what level of training is required for competence in making a particular engineering decision, and more in its reductive, black-and-white thinking about relative degrees of competence, as if exactly eight semesters of engineering coursework is required for one to be a "full" engineer, any less than that relegating the graduate to the status of not-engineer, and hence of questionable pedigree. Further on, the authors make a similar point about how the line between (qualified) engineer and (wholly unqualified) non-engineer gets drawn, but this time coming from the perspective of employers. They suggest, "While most employers valued the engineering-savvy non-engineer, others voiced concern about having a 'half-trained' nonengineer assuming engineering duties." 15 Most engineering practitioners likely recognize that, of the wide range of activities they carry out, many do not entail or require sophisticated technical analysis and judgment: Many such engineers even qualify that they only do a small portion of (real) "engineering" work in their day-to-day. Engineering qualifications and engineering professional work requirements both exist on a continuous scale, along multiple dimensions of engineering practice: technical analysis, design, risk estimation, communication. There is no one, uniquely distinguishable, clearly delineated technical qualification for all of engineering.

There's also the problem that the "half-trained" engineer in this framing remains half-emptythe presumption is that relevant, complementary expertise does not constitute the remainder of the candidate's education or expertise. Certainly, there is terminological wiggle-room created in the claim that these undertrained non-engineers should not be assigned to "engineering duties," whereas they might be just fine for "non-engineering" duties within the same organizational context. But this qualification merely begs the question of what constitutes "engineering duties" to begin with, a question that will be taken up more systematically below.

Another dimension of the disciplinary elitism built into the cases is how "engineering" as a domain of inquiry is understood as relating to liberal education as an educational philosophy and framework that spans diverse domains of inquiry, each with its distinctive ways of inquiring. In other words, is engineering understood as one of many valid ways of viewing the world? Or is it held up as a "super-discipline" that already encompasses other ways of knowing, obviating the need to study other subject areas of their unique modes of inquiry?

The EELE case briefs include instances where authors clearly understand and appreciate the centrality of "multiple ways of knowing" in liberal education, and many of them situate engineering as one approach among others within a contemporary liberal education. The strongest example of this appreciation in the case briefs is from Macalester's proposed course 
“Thinking Like an Engineer." The course's description addressed the relationship of engineering to liberal education explicitly:

[B]y putting the primary emphasis on the process of thinking rather than the end result, we want to send the message that engineering is not just about the grand achievements of great minds but also about a way of reflection and a form of practice in which many can participate. We hope to expose students to the variety of types of knowledge involved in engineering design and, by so doing, help them to understand that engineering knowledge is at bottom interdisciplinary knowledge — knowledge involving ways of thinking that reflect a number of disciplines in the liberal arts and sciences. Students will learn to see that a design problem isn't solely a technical problem, but is inseparable from ethical, social, political, and historical dimensions. ${ }^{16}$

Here we see an understanding of engineering modes of inquiry as one set among many legitimate ways of knowing the world as well as recognition that there are multiple ways of knowing the world within engineering. This type of framing, we believe, represents exemplary thinking about the relationship of engineering to liberal education ways of knowing.

Framing engineering as an essential component of liberal education is compelling, and it should serve as a model for other EELE approaches. The authors of the case make their justification explicit:

[W]e could raise the question of whether given the massive transformations to the lived human environment made by engineering, reflection on these changes should be included within the compass of a liberal arts education. Our response to this question is an unqualified yes. ${ }^{16}$

Similarly, the Wellesley case highlights the need for critical engagement around engineering and technology's relationship to the human condition:

Liberally trained students must be able to engage critically with content related to engineering and technology. To consider and address many of humanity's biggest challenges and opportunities ... highly interdisciplinary thinking and collaboration is required. ${ }^{17}$

Rather than simply asserting that technology drives positive social transformation (see the following section on technological determinism), these authors argue for the importance of reflecting on such transformations, and with an interdisciplinary approach, as a component of liberal education.

David Billington's work at Princeton, although problematic in other ways described in this paper, frames "engineering literacy" as an integral element of liberal education, but within a broad array of literacies. In the spirit of liberal education as an education foundation, Tobias indicates that he suggests:

The same [engineering] literacy should also be the foundation of how engineers are introduced to engineering. Engineering education, today, he says, teaches "best 
practices," which refer to standardized knowledge and methods of solving problems.

These are the kind of knowledge essential to the work that most engineers actually do.

But they do not encourage deeper innovation or explain how it comes about. ${ }^{18}$ Rather than focusing only on best practices, which we assume refers to engineering problemsolving methods, engineering education is insufficiently attentive to the forces that shape how engineers solve problems. ${ }^{18}$ Directing inquiry to how engineers solve problems and why they do it the way they do opens engineering to other liberal-art disciplines in a manner that is productive for all participants.

Unfortunately, the case briefs also include several instances where authors seem to suggest that engineering ways of knowing offer a compelling alternative to the liberal education framework, less by explicitly dismissing the foundations of liberal education and more by centering engineering knowledge as the necessary (and possibly sufficient) variable in understanding technology in society. This framing inadvertently undermines liberal education's foundation of conveying multiple ways of knowing. The commonly articulated refrain is captured by the Computer Ethics course instructor in the Delaware case:

Every one of us is faced with using modern technology every day. Our cell phone, our computer, our car, the internet... It is important that we educate students to understand the basics about how this technology works. Furthermore, as citizens, we are asked to deal with complex issues, such as cyber security. To be able to understand and vote on such issues requires a basic understanding of the underlying technical concepts. ${ }^{19}$

The logic here indicates that it is necessary to understand "underlying technical concepts" in order to effectively use a cell phone or computer and that it is necessary to understand these same underlying technical concepts to participate in democratic technology policymaking. In a similar vein, Tobias quotes Susan Voss as saying, "no one can learn ... about engineering who hasn't designed or built or measured something.", "20

On a superficial level, it makes perfect sense that more information about technology principles and operations, as well as technology-making practices, should help students in understanding how a given technology fits within its larger social context. On a deeper level, however, it is not logical to claim narrow technical expertise is required for functional literacy about technology use, for assessing the acceptability of broad-impact risks created by technologies, or for anticipating the social impact of technologies whose relationship to social action and interaction transcends underlying technical principles. Understanding underlying technical principles are necessary for designing technologies, surely, but rarely so for understanding how those technologies play out in the social world.

Following directly from the epistemological elitism common across the cases is a distinct obsession with quantification and empiricism as the only valid ways of knowing. For example, at Princeton, "Simplified numerical studies are a first essential part of any attempt to communicate 
to liberal arts students the essence of engineering." 18 The need to "simplify" the studies for nonengineering students reveals again the presumptions of engineering's superiority; further, the characterization of non-engineering students as "liberal arts students" belies the notion, expressed elsewhere in Princeton's account, that engineering is but one of many ways of knowing within liberal education. Indeed, in this case, liberal arts students are held separate from engineering students, or indeed all students with quantitative disciplinary backgrounds.

Similarly, at Delaware, the case editor's reflection on the highlighted course concludes: Goals for the next [offering] would be to increase the level of sophistication of class discussions as well as finding ways to have the non engineering students become more comfortable with engineering calculations. ${ }^{21}$

This equation of engineering with quantification is a primary vehicle used to maintain a hierarchy in which engineering remains on top, and non-engineering students continue to be demoted relative to engineering students until they can "measure up."

All of these forms of empirical elitism are facilitated by an internalist disposition regarding engineering, that is to say, developments within engineering occur in a social vacuum, unaffected by external influences. There is a presumption of purity in this, so that all that matters are the measurement, the calculation, the estimation. In this prototypical "engineering way of knowing," these quantification practices produce an incontrovertible and objective truth, unfettered by political, social, or economic forces, and absent anything to do with people. The insistence that this is the most important thing for non-engineers to learn about engineering in a liberal education context both misses key avenues for connecting with students from other disciplines and reveals simplistic assumptions held by engineering educators about the relationship between technology and society, discussed further in the next section.

\section{Technological Determinism: Too Simple a Model for the Technology-Society Relationship in a Liberal Education Context}

In addition to epistemological elitism, another thread of conceptual shortcomings is stitched through the EELE cases. This one involves the implied or stated model for characterizing the relationship between technology and society. Most simply, we characterize the predominant approach to the technology-society relationship in the cases as "technological determinism," a concept that is core to the discipline of science and technologies studies. Technological determinism has two primary components. First is that technology drives social change in a oneway relationship that ignores the social circumstances and conditions that lead to various forms of technology development to begin with. Second is that technology's developmental trajectory is somehow "built in"-internal to the logic of any given technological domain. 
At Princeton, we see a clear if implicit example of technological determinism: "Engineering in the Modern World focuses on great works of engineering, ones that caused a radical shift in American society, and on a small number of successful key innovators." ${ }^{22}$ Not only does the course follow a "great (mostly white) men in history" model, but here the great men create great technologies that then shape society, with little apparent attention to the influence of socialhistorical contexts. ${ }^{23}$ In Billington's own words (as conveyed by Tobias), the course is presented "in a way that art historians teach the history of art, by focusing on great works and the personalities and ideas of their creators." ${ }^{24}$ Note here that although in most cases artists may be reasonably said to be sole creators of their work, hardly the same can be said of engineering marvels, which come into begin through tremendous, coordinated human, financial, and organizational effort that would be difficult to capture by looking only at the protagonist engineer. Additionally, as a discipline, art history tends to situate the great artists within their respective historical movements, drawing connections between the individual, contemporaries, and the broader cultural forces (e.g., the zeitgeist) shaping it all. In this way, art history layers understanding of the complexity of "historical unfolding" rather than reducing history to a didactic account of the great works of great individuals.

At one point, it almost looks as if the broader context of engineering will be acknowledged in the Princeton case: Among several organizing ideas for the given approach was one opening with "Engineering is a human activity ...." But the remainder of the description unveils how human agency is actually construed in the course: "Engineering is a human activity, which often reflects the thoughts and feelings of individual engineers. Thus, [another] essential part of this program in engineering education is the study of the lives of pioneering engineers." ${ }^{18}$ In addition to its celebration of and focus on great engineers, the Princeton course also presents technologies as the primary if not exclusive shapers of historical change. "Through the lens of engineering innovation, the growth of America is presented as a developing progression. First, as a colonial nation ...; then ... carrying out its own manufacturing...; then proceeding to connecting its borders with information.... Finally, to a position of dominance in the world industries..."25 This account of US history presents as a version of manifest destiny-except here appropriated as a direct result of technological development, rather than as a pervasive mindset among $19^{\text {th }}$ century Americans that drove political and military doctrine. Further, in the Princeton course, students read autobiographies of the great innovators as a way of understanding the motivating forces behind the engineers being studied, further solidifying the project as one of internalist history.

The framework of history as "linear human progress through technology (and scientific) advance" underlies other EELE educational initiatives conveyed in the cases. At Delaware, the case profile highlights the stakes: "A public that does not understand science can represent a significant threat to future scientific progress." ${ }^{26}$ While in the age of Trump, public rejection of science may appear even more important to acknowledge than ever in contemporary times, the 
presumption underlying the claim is that ignorance comes from not knowing scientific "facts," rather than the wholesale rejection of the critical and analytical thinking underlying a scientific worldview. To illustrate our critique, the Delaware case goes on to dismiss concerns over the risks and ethics of nanotechnology development as follows: "To a significant fraction of the public, nanotechnology represents a menace to be controlled ... fear of the unknown led the city of Berkeley to regulate — and nearly ban — nanotechnology in late 2006."27 By casting the public as ignorant and scientists/engineers as both knowing and unassailable, even and especially in the rollout of new, complex technologies with uncertain effects, technology is cast not only as the driver of history, but as the very foundation of progress. ${ }^{28}$

Delaware's Honors History of Technology course maps a slightly more nuanced version of technology in history. The course includes attention to several antecedents to the industrial revolution, and attempts to help students think through the relationship between technology and historical development in a systematic way: "It was explained by the instructor that any phenomenon could be a cause or an effect or simply coincident with the onset of the industrial revolution." However, what the case analysis presents as a sophisticated decomposition of historical causality actually hides a deterministic, one-way impact model of technology and society. This understanding of the relationship is made clear further on in the case: "The purpose of the course was to give students a general understanding of the technological innovations that undergird modern society.... That there were significant gaps in students' general knowledge, was made clear when Heck inquired informally at the onset of the course, how many were able to identify James Watt, Robert Fulton or John Roebling or even Werner von Braun." ${ }^{\text {,2 }}$ Not only are technological innovations (read, "cause") driving history (read, "effect"), but students are expected to attribute those innovations singularly to great (white male) individuals (read, the cause of the cause), in keeping with the Billington model.

Smith takes a more balanced stance with respect to the historical role of engineering, offering a more sophisticated interpretation of the technology-and-society relationship: "The work of engineers both exacerbates and offers solutions to some of our gravest societal problems, including climate change, disease, resource limitations, and conflict." ${ }^{30}$ Similarly, Stony Brook's Learning from Disasters course highlights how "understanding what happened and why [around historical disasters] is never simple. Rather, it is a combination of factors.... A small unanticipated change in the environment of a structure or a system can cause a problem, and as systems become more complex, they can react in a non-linear way." 31 Topics included in the course include attention to the fact that "engineers themselves are not entirely rational and unemotional when they are attracted to a project," which is exemplified in the course by the book, Drilling Down, about deep water drilling. "Students are instructed in the 'energy/complexity spiral': that increasing complexity in modern society requires more energy, which in turn leads to the creation of yet more complex technology...."31 Rather than relying on the trope "great innovators create great technologies that create social progress," these 
institutions squarely tackle the trade-offs, the risks, the uncertainties, and the costs of engineering endeavors, thereby aligning more comfortably with liberal educational approaches and learning goals.

Another dimension of technological determinism is the logical separation of that which is technology and that which is society. This separation is known within science and technology studies as "technosocial dualism," where technology and society are cast as distinct, mutually exclusive domains. A disciplinary version of technosocial dualism pervades much of the work in ELE integration. In the Williams College EELE case, "students met in discussion sections, where it was not inappropriate (as it might have been in most science classes) to explore students' beliefs and opinions on [questions of reproductive technologies]." 32 While this claim is certainly not factually incorrect, the quotation highlights the line typically drawn between presumably neutral matters of science and engineering, which are not open to "discussion," and the "beliefs and opinions" of students that are relevant only in the domains of the non-sciences.

At Hope College, the split between the technical and the social worlds is also evident. In that context, we see terminology of domains that are internal or external to engineering:

"Technological systems, like the automobile and the electric grid, in turn, have to be understood in their interaction with outside systems: social, cultural and economic." 33 These "outside systems" are perceived to be separable from the technical, rather than complexly intertwined, as in the Wellesley and Smith cases described above. In the understanding of the Hope course, "systems are made up of individual components that provide specific functions...."33 If applied to social, cultural, and economic systems, such an approach would likely be similar to structural functionalism in sociology, subject to the same limitations and concerns.

\section{Engineering Fundamentals:}

\section{Considering What Knowledge Is Core Is Core to Liberal Education}

Explicit, regular referencing of engineering "fundamentals" also occurs as a thematic pattern across the EELE cases, with fundamentals varying in definition but generally referring to engineering science content and the incorporation of mathematics or quantification in engineering analysis. At Wellesley, the course "Fundamentals of Engineering ... is intended to be a rigorous introduction to the 'big ideas' of engineering, offering students a strong foundation in preparation for [sic] engineering coursework at MIT or Olin College."34 Unlike the "big ideas" approach used at Princeton, here the course covers themes such as mechanism design, feedback and control, modeling, and a project-based design capstone. The emphasis on "rigor" is perhaps not surprising given the potential of the course to serve as a prerequisite for other engineering coursework. As a women's college, this emphasis on rigor may also be doing a certain kind of work at Wellesley in establishing qualifications for female students seeking to enter more malefocused environments. 
At Smith College, engineering fundamentals is cast to include hands-on work, design, experimentation, and exploration, taking more of an engineering-practices focus. Smith faculty "intended a broad background in engineering fundamentals and engineering thinking" in designing the course. ${ }^{35}$ This may be because a second-semester course for majors on mass and energy balances covers topics in an engineering science frame, focused on problem solving and engineering analysis. Yet another perspective on engineering fundamentals is offered at Macalester College, where the focus is on what engineers know, how engineers think, and how they think about what they know, as detailed earlier in this paper. Finally, Stony Brook's Learning from Engineering Disasters course provides a systematic mix of "engineering concepts" and a "broader system/context" in a series of case studies of engineering disasters. ${ }^{31}$ The broader system/context content provides the disasters addressed both historical and contemporary context, highlighting the relevance of the disaster to students but also concretizing the engineering concept by linking it to broader social issues and goals that bear on it.

\section{Conclusions: Engineering as a Component of Liberal Education}

The analysis presented in this paper is part of a larger research initiative being carried out by the authors, which interrogates a wider range of approaches to ELE integration with the goal of identifying the strategic and conceptual dimensions that drive them and some of their associated underlying assumptions. ${ }^{36,37}$ The larger project seeks to provide a map of current and proposed engineering programs that explicitly highlight ELE integration, drawing particularly on venues such as ASEE Liberal Education/Engineering and Society Division, Union College's annual Engineering and Liberal Education Symposium, and the related set of initiatives around the theme of engineering and social justice as well as some of the many books, professional society and government reports, and strategic initiatives by foundations.

As described in the introduction, our analysis of ASEE's Engineering-Enhanced Liberal Education (EELE) initiative is situated within a larger project to map the much broader scholarship on Engineering and Liberal Education (ELE). The ELE mapping project began at the Union College Symposium on Engineering and Liberal Education three years ago. Sitting together after a day of sessions, we lamented that too many approaches to ELE seemed to "manifest ... the conceptual trappings of traditional engineering epistemologies," by which we meant they inadvertently reinforced an instrumentalist and reductivist worldview even as they employed content, methodologies, and educational activities drawn from the humanities, arts, and social sciences. Our response was not specifically focused on the presentations of the day, but rather to the larger field of engineering and liberal education integration, not least including our own efforts. At that time, we were convinced that engineering could best contribute to liberal education by understanding the epistemological and pedagogical foundations of liberal education and situating itself within that framework rather than forever situating ourselves apart. The EELE 
case studies, though embodying a variety of positive efforts in this regard, tend overwhelmingly to impose a patently engineering worldview upon liberal education instead of participating as one among many equally valid ways of knowing that is fundamental to liberal education.

This paper has enumerated numerous instances in which some of the best intended and most serious efforts toward "enhancing liberal education" - in this case, those offering engineering courses and programs for non-engineering majors - wittingly or unwittingly undermine or even abandon the foundational principles of liberal education. They do so in very different ways, but they commonly reflect inadequate understandings of or engagement with other disciplines and their ways of inquiry. These are not merely incomplete accounts, as is necessarily the case when reaching across disciplines, but are deeply flawed in that they do not afford other ideas and other ways of knowing their due place in the context of a liberal education framework. This calls us to critically reflect upon the inadequacies of our own undergraduate engineering educations, and to take lifelong learning seriously enough to approach our own work with additional humility.

This analysis is sobering and daunting. We believe it is too flippant and facile to presume, as Tobias offers in the Honors Programs case "Postscript," that

engineers should not be put off by difficulties or objections. "Engineers," we are told, "don't find excuses, they find solutions."

Indeed, would it be so that our critiques herein will be readily heard and absorbed, and we might together find our way beyond easy fixes to loosening engineering's grip on the One Right/Best Answer in order to enable real engagement and mutual learning with other epistemic worlds.

\section{References}

${ }^{1}$ Helguera, P. (2011). Education for Socially Engaged Art. Jorge Pinto Books Inc. P. xiv.

${ }^{2}$ ASEE and The Teagle Foundation, Engineering-Enhanced Liberal Education Project, "Introduction." Web. Last accessed 12 February 2017 at https://www.asee.org/engineeringenhanced-liberal-education-project/introduction.

${ }^{3}$ American Association of Colleges and Universities (AAC\&U). (2017). "What is a 21st Century Liberal Education?” Web. Last accessed 12 February 2017 at https://www.aacu.org/leap/what-isa-liberal-education.

${ }^{4}$ AAC\&U. (2017). "What is a 21st Century Liberal Education?" Web. Last accessed 12 February 2017 at https://www.aacu.org/leap/what-is-a-liberal-education.

${ }^{5}$ Author2, 2015.

${ }^{6}$ Author2 and Author 1, 2016.

${ }^{7}$ Tobias, S. Engineering-Enhanced Liberal Education Project, "Introduction." Web. Last accessed 12 February 2017 at https://www.asee.org/documents/teagle/TobiasIntro.pdf 
${ }^{8}$ Berg, B. L. and Lune, H. (2013). "Introduction to Content Analysis.” In Qualitative Research Methods for the Social Sciences, 8th ed. Pearson, pp. 373-410.

${ }^{9}$ Gee, J. P. (2004). "Discourse Analysis: What Makes It Critical." In An Introduction to Critical Discourse Analysis in Education, R. Rogers, ed. Lawrence Erlbaum Associates, pp. 19-50.

${ }^{10}$ Tobias, S. (2016). Engineering-Enhanced Liberal Education Project, "Introduction.” P. 1. Last accessed 12 February 2017 at https://www.asee.org/documents/teagle/TobiasIntro.pdf.

${ }^{11}$ Tobias, S. (2016). Engineering-Enhanced Liberal Education Project, "Introduction." P. 2. Last accessed 12 February 2017 at https://www.asee.org/documents/teagle/TobiasIntro.pdf.

${ }^{12}$ Tobias, S. (2016). UNIVERSITY of DELAWARE: “'All the Elements in Place' for a Program." P. 2. Last accessed 12 February 2017 at https://www.asee.org/documents/teagle/UnivDelaware.pdf.

${ }^{13}$ Mina, M., Krupcazk, J., and Abrams, L. (2016). "The Engineering Minor: Two Cases and an Analysis." Pp. 3-4. Last accessed 12 February 2017 at https://www.asee.org/documents/teagle/Minors.pdf.

${ }^{14}$ Mina, M., Krupcazk, J., and Abrams, L. (2016). “The Engineering Minor: Two Cases and an Analysis." P. 6. Last accessed 12 February 2017 at https://www.asee.org/documents/teagle/Minors.pdf.

${ }^{15}$ Mina, M., Krupcazk, J., and Abrams, L. (2016). "The Engineering Minor: Two Cases and an Analysis." P. 8. Last accessed 12 February 2017 at https://www.asee.org/documents/teagle/Minors.pdf.

${ }^{16}$ Flath, D. and Michelfelder, D. (2016). "Thinking Like an Engineer: Proposed First Year Course for Fall 2016." P. 1. Last accessed 12 February 2017 at https://www.asee.org/documents/teagle/Thinking-Like-an-Engineer.pdf.

${ }^{17}$ Banzaert, A. and Ducas, T. (2016). "Technology and Engineering at Wellesley College: A Case Study." P. 4. Last accessed 12 February 2017 at https://www.asee.org/documents/teagle/WellesleyCollege.pdf.

${ }^{18}$ Tobias, S. (2016). "PRINCETON UNIVERSITY.” P. 8. Last accessed 12 February 2017 at https://www.asee.org/documents/teagle/Princeton-Univ.pdf.

${ }^{19}$ Tobias, S. (2016). UNIVERSITY of DELAWARE: “"All the Elements in Place' for a Program." P. 6. Last accessed 12 February 2017 at https://www.asee.org/documents/teagle/UnivDelaware.pdf.

${ }^{20}$ Tobias, S. (2016). "SMITH College." P. 4. Last accessed 12 February 2017 at https://www.asee.org/documents/teagle/SMITH.pdf.

${ }^{21}$ Tobias, S. (2016). UNIVERSITY of DELAWARE: “'All the Elements in Place' for a Program." P. 3. Last accessed 12 February 2017 at https://www.asee.org/documents/teagle/UnivDelaware.pdf.

${ }^{22}$ Tobias, S. (2016). "PRINCETON UNIVERSITY.” P. 1. Last accessed 12 February 2017 at https://www.asee.org/documents/teagle/Princeton-Univ.pdf.

${ }^{23}$ While the EELE site does not provide full syllabi for courses described, it does offer additional details on the subjects covered and, for some cases such as the Princeton course, a course schedule. The Princeton course schedule indicates three areas of focus for each of class topics: Innovator (e.g., engineer), key innovation (e.g., the transformative instance of the technology), the technology domain ushered in by the prototypical instance.

${ }^{24}$ Tobias, S. (2016). "PRINCETON UNIVERSITY.” P. 7. Last accessed 12 February 2017 at https://www.asee.org/documents/teagle/Princeton-Univ.pdf. 
${ }^{25}$ Tobias, S. (2016). "PRINCETON UNIVERSITY.” P. 4. Last accessed 12 February 2017 at https://www.asee.org/documents/teagle/Princeton-Univ.pdf.

${ }^{26}$ Tobias, S. (2016). UNIVERSITY of DELAWARE: “"All the Elements in Place' for a Program." P. 7. Last accessed 12 February 2017 at https://www.asee.org/documents/teagle/UnivDelaware.pdf.

${ }^{27}$ Tobias, S. (2016). "PRINCETON UNIVERSITY.” P. 7. Last accessed 12 February 2017 at https://www.asee.org/documents/teagle/Princeton-Univ.pdf.

${ }^{28}$ Marx, L. (1987). “Does Improved Technology Mean Progress?” Technology Review, 90(1), 33-41.

${ }^{29}$ Heck, R. (2016). “Teaching Technology in an Honors Program - A Model.” Pp. 4-5. Last accessed 12 February 2017 at https://www.asee.org/documents/teagle/Honors.pdf.

${ }^{30}$ Tobias, S. (2016). "SMITH College." P. 6. Last accessed 12 February 2017 at https://www.asee.org/documents/teagle/SMITH.pdf.

${ }_{31}^{31}$ Tobias, S. (2016). "STONY BROOK UNIVERSITY: NEW COLLEGE-WIDE TECH REQUIREMENT." Last accessed 12 February 2017 at

https://www.asee.org/documents/teagle/StonyBrook.pdf.

${ }^{32}$ Tobais, S. (2016). “WILLIAMS COLLEGE.” P. 1. Last accessed 12 February 2017 at https://www.asee.org/documents/teagle/WilliamsCollege.pdf.

${ }^{33}$ Tobias, S. (2016). "Hope College." P. 2. Last accessed 12 February 2017 at https://www.asee.org/documents/teagle/HopeCollege.pdf.

${ }^{34}$ Banzaert, A. and Ducas, T. (2016). "Technology and Engineering at Wellesley College: A Case Study." P. 6. Last accessed 12 February 2017 at https://www.asee.org/documents/teagle/WellesleyCollege.pdf.

${ }^{35}$ Tobias, S. (2016). "SMITH College." P. 2. Last accessed 12 February 2017 at https://www.asee.org/documents/teagle/SMITH.pdf.

${ }^{36}$ Author2, 2015.

${ }^{37}$ Author2 and Author 1, 2016. 